\title{
Two new species and five newly recorded species of the genus Udea Guenée from China (Lepidoptera, Crambidae)
}

\author{
Dandan Zhang', Jinwei Li' \\ I Institute of Entomology/State Key Laboratory of Biocontrol/The Museum of Biology, Sun Yat-sen University, \\ Guangzhou, Guangdong 510275, China \\ Corresponding author: Dandan Zhang (zhangdd6@mail.sysu.edu.cn)
}

Academic editor: M. Nuss | Received 22 August 2015 | Accepted 22 December 2015 | Published 17 February 2016

http://zoobank.org/BF30F43F-186B-4739-AC09-2C19D57B2956

Citation: Zhang D, Li J (2016) Two new species and five newly recorded species of the genus Udea Guenée from China (Lepidoptera, Crambidae) ZooKeys 565: 123-139. doi: 10.3897/zookeys.565.6304

\begin{abstract}
A checklist of the 31 Chinese species of Udea is given, including the new species and new records. Udea curvata sp. n. and $U$. albostriata sp. n. are described and illustrated. Udea exigualis (Wileman, 1911), U. stationalis Yamanaka, 1988, U. prunalis (Denis \& Schiffermüller, 1775), U. elutalis (Denis \& Schiffermüller, 1775) and $U$. cyanalis (La Harpe, 1855) are newly recorded for China.
\end{abstract}

\section{Keywords}

Lepidoptera, Crambidae, Udea, checklist, taxonomy, China

\section{Introduction}

Udea Guenée is a large genus, with more than 210 species, and is mainly distributed in the temperate Eurasia and in the New World, with a remarkable number of endemic species occuring on islands in the Pacific and Atlantic Oceans, on the Hawaiian Islands and some other islands (Nuss et al. 2003-2014; Mally and Nuss 2011; Slamka 2013). Udea is usually placed in the Spilomelinae (Munroe 1995; Solis and Maes 2003), but this placement is not confirmed by phylogenetic study (Mally and Nuss 2011). 
Morphology and genitalia of Udea are simple and uniform throughout the genus. Species of Udea are dark to light greyish, brown, reddish-yellow, dark yellowish or pale yellow; the forewing has a circular and a reniform cellular stigmata; the hindwing bears a streak at the anterior angle and a dot at the posterior angle of cell; the wings usually with marginal dots at ends of veins. Male genitalia with uncus inverted T-shaped, apex bulbous, with setae; fibula extending ventrad to distad. Corpus bursae usually with a large lanceolate, denticulate signum in female genitalia.

Important taxonomic contributions on Udea were published by Munroe (1950, 1966, 1989, 1995), Zimmerman (1958), Hannemann (1964), Inoue (1982), Yamanaka (1988), Inoue et al. (2008), Mally and Nuss (2011) and Slamka (2013). Chinese species of Udea were reported by Walker (1859), Hampson (1899, 1918), Sauber (1899), Leech and South (1901), Zerny (1914), Strand (1918), Caradja (1916, 1925, 1927, 1928), Caradja and Meyrick (1937) and Yamanaka (1972). Two new species and five newly recorded species for China are presented in this study, bringing the total to 31 species recorded in China.

\section{Material and methods}

This study is based on the examination of specimens collected by using light traps. Terminology of the genitalia follows Maes (1995), Mally and Nuss (2011) and Slamka (2013). Genitalia dissection and mounting methods follow Robinson (1976) and Li and Zheng (1996), with some modification. The specimens are deposited in the Biology Museum, Sun Yat-sen University (SYSBM) except those specified with the Insect Collection, College of Life Sciences, Nankai University (NKUM).

\section{Results}

\section{Checklist of Chinese Udea species}

\section{Udea Guenée, 1845}

Udea Guenée in Duponchel, 1845: 209. Type species: Pyralis ferrugalis Hübner, 1796, by monotypy.

\section{Udea albostriata sp. n.}

Distribution. China (Hebei).

Udea aksualis (Caradja, 1928) (as Pionea)

Distribution. China (Xinjiang).

Udea austriacalis (Herrich-Schäffer, 1851) (as Botys)

Scopula donzelalis Guenée, 1854

Botys sororialis Heyden, 1860 
Botys nitidalis Heinemann, 1865

Pyrausta austriacalis altaica Zerny, 1914

Pyrausta austriacalis juldusalis Zerny, 1914

Distribution. China (Xinjiang), Russia (Altai), France, Switzerland, Austria, Romania, Bulgaria, Albania.

Udea conubialis Yamanaka, 1972

Distribution. China (Taiwan).

Udea costalis (Eversmann, 1852) (as Botys)

Botys hilaralis Christoph, 1881

Botys hyperborealis var. hoffmanni Krulikovsky, 1898

Pionea costalis var. alaicalis Caradja, 1916

Pionea costalis var. alaicalis f. brunnealis Caradja, 1916

Mesographe itysalis maurinalis Curtis, 1934

Distribution. China (Xinjiang), Mongolia, Russia (Far East, Siberia, Altai), France, Lithuania, Poland.

\section{Udea curvata sp. $\mathbf{n}$.}

Distribution. China (Tibet).

Udea cyanalis (La Harpe, 1855) (as Botys), new record to China

Distribution. China (Hebei), Spain, France, Herzegovina, Romania, Germany, Central Urals, Russia (Caucasus).

Udea decrepitalis (Herrich-Schäffer, 1848) (as Botys)

Pionea decrepitalis ab. leucoalis Strand, 1920

Distribution. China (Hebei, Qinghai) (Xu, 1997), Europe.

Udea defectalis (Sauber, 1899) (as Botys)

Distribution. China (Qinghai).

Udea elutalis (Denis \& Schiffermüller, 1775) (as Pyralis), new record to China Pyralis albidalis Hübner, 1796

Distribution. China (Hebei, Xinjiang), Kazakhstan, West Europe, Central Europe, Romania, Balticum, Finland, Russia (Siberia).

Udea endotrichialis (Hampson, 1918) (as Hapalia)

Distribution. China (Taiwan).

Udea exigualis (Wileman, 1911) (as Pionea), new record to China

Distribution. China (Fujian, Guangxi, Guizhou, Hubei, Hunan, Sichuan, Tibet, Yunnan), Japan. 
Udea ferrugalis (Hübner, 1796) (as Pyralis)

Scopula martialis Guenée, 1854

Scopula hypatialis Walker, 1859

Pionea maculata Costantini, 1923

Pionea obsoleta Costantini, 1923

Pionea granjalis Chrétien, 1925

Udea martialis f. fusca Dufrane, 1960

Udea martialis f. pallida Dufrane, 1960

Distribution. China (Gansu, Guangdong, Guizhou, Hebei, Henan, Hubei, Hunan, Jiangsu, Qinghai, Shaanxi, Shandong, Shanxi, Shanghai, Sichuan, Taiwan,

Tianjin, Yunnan, Zhejiang), widely distributed in Asia, Europe and Africa.

Udea flavofimbriata (Moore, 1888) (as Mabra)

Botys obealis Snellen, 1899

Distribution. China (Guangdong, Taiwan), Japan, Myanmar, Indonesia (Sumatra, Java), India, Sri Lanka.

Udea fulcrialis (Sauber, 1899) (as Botys)

Distribution. China (Qinghai).

Udea incertalis (Caradja in Caradja \& Meyrick, 1937) (as Pionea)

Distribution. China (Yunnan).

Udea lugubralis (Leech, 1889) (as Botys)

Distribution. China (Fujian, Guizhou, Henan, Hubei, Hunan, Shaanxi, Sichuan, Yunnan, Zhejiang), Korea, Japan, Russia (Sakhalin, Shikotan Island, Ussuri, Amur).

Udea nigrostigmalis Warren, 1896

Distribution. China (Guangdong), India.

Udea montensis Mutuura, 1954

Distribution. China (Hubei, Sichuan) (Song, 2001), Japan.

Udea orbicentralis (Christoph, 1881) (as Botys)

Distribution. Western China, Korea, Japan, Russia (Vladivostok).

Udea planalis (South in Leech \& South, 1901) (as Pionea)

Distribution. China (Sichuan).

Udea poliostolalis (Hampson, 1918) (as Hapalia)

Distribution. China (Taiwan). 
Udea prunalis (Denis \& Schiffermüller, 1775) (as Pyralis), new record to China Phalaena nivealis Fabricius, 1781

Phalaena Pyralis ferruginalis Villers, 1789

Pyralis leucophaealis Hübner, 1796

Pyralis nebulalis Haworth, 1811

Distribution. China (Gansu, Heilongjiang, Ningxia, Shanxi, Sichuan, Xinjiang), Europe (except some of Mediterranean Islands).

Udea russispersalis (Zerny, 1914) (as Pionea)

Distribution. China (Xinjiang).

Udea schaeferi (Caradja in Caradja \& Meyrick, 1937) (as Pionea)

Distribution. China (Yunnan).

Udea scoparialis (Hampson, 1899) (as Pionea)

Distribution. China (Tibet).

Udea stationalis Yamanaka, 1988, new record to China

Distribution. China (Fujian), Japan.

Udea subplanalis (Caradja in Caradja \& Meyrick, 1937) (as Pionea)

Distribution. China (Yunnan).

Udea suisharyonensis (Strand, 1918) (as Pionea)

Pionea lolotialis Caradja, 1927

Distribution. China (Sichuan, Taiwan).

Udea thyalis (Walker, 1859) (as Botys)

Distribution. China, Japan.

Udea tritalis (Christoph, 1881) (as Botys)

Distribution. Northern China, Korea, Japan, Russia (Ussuri) (Inoue, 1993).

\section{Descriptions of new species and diagnoses of new records to China}

\section{Udea exigualis (Wileman, 1911), new record to China}

Pionea exigualis Wileman, 1911: 388. Type locality: Japan.

Udea exigualis (Wileman): Inoue 1982: 364.

Diagnosis. This species is similar to other species of $U$. lugubralis-complex. It can be distinguished from $U$. lugubralis by smaller size (wingspan 16-21 $\mathrm{mm}$ ) and longer harpe 
with sharp point. It differs from $U$. stationalis and $U$. montensis by bent harpe with sharp point. Its phallus apodeme lacking a small lateral tooth-like process is different from $U$. montensis. $U$. exigualis is similar to $U$. ferrugalis and $U$. testacea (Butler) with yellowishbrown forewing bearing dark brown fringe, but can be distinguished in male genitalia by the more slender and shorter fibula and the juxta without dorsal arms.

Material examined. China: Fujian: $1 \hat{\gamma}$, Yong'anyan, Mt. Daiyunshan, 1300 m, $12-$

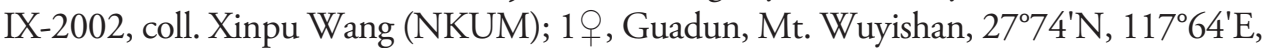
1220 m, 18-V-2012, coll. Jinwei Li, genitalia slide no. LJW12156; Guangxi: 10, Gaozhai, Xing'an, 28-VIII-2011, coll. Jinwei Li, genitalia slide no. LJW12253; 7ठ․, Anjiangping Reserve, $25^{\circ} 33^{\prime} \mathrm{N}, 109^{\circ} 55^{\prime} \mathrm{E}, 1751 \mathrm{~m}, 10-\mathrm{VII}-2013$, coll. Xiaohua Chen, genitalia slide

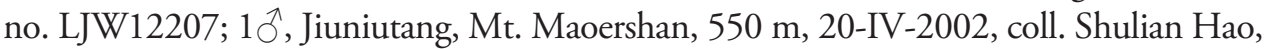

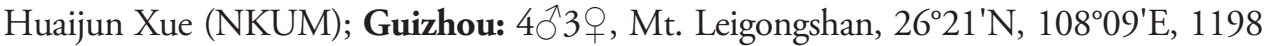
m, 14-15-VII-2013, coll. Xiaohua Chen, genitalia slides no. LJW12255 (), LJW12269

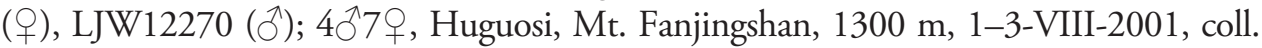
Houhun Li, Xinpu Wang (NKUM); 10, Jinding, Mt. Fanjingshan, 2100 m, 31-VII2001, coll. Houhun Li, Xinpu Wang (NKUM); 1q, Huixiangping, Mt. Fanjingshan, 1700 m, 1-VI-2002, coll. Xinpu Wang (NKUM); 10̄, Suoluo, Chishui, 390 m, 30-V2000, coll. Yanli Du (NKUM); Hubei: $10^{\wedge}$, Jiuhuping, Shennongiia, $31^{\circ} 30^{\prime} \mathrm{N}, 110^{\circ} 21^{\prime} \mathrm{E}$,

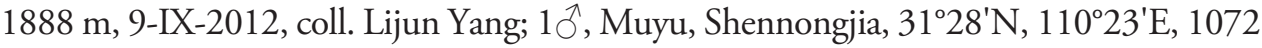
$\mathrm{m}$, 8-IX-2012, coll. Jinwei Li, genitalia slide no. LJW12150; 1우 Maoping, Wufeng, $30^{\circ} 08^{\prime} \mathrm{N}, 110^{\circ} 40^{\prime} \mathrm{E}, 1175 \mathrm{~m}, 12-\mathrm{IX}-2012$, coll. Lijun Yang, genitalia slide no. LJW12263;

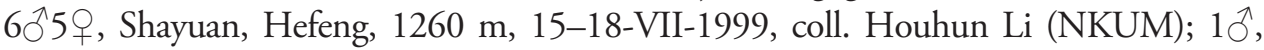
Houhe, Wufeng, 1100 m, 11-VII-1999, coll. Houhun Li (NKUM); $5 \hat{\text { }}$, Pingbaying, Xianfeng, 1280 m, 21-22-VII-1999, coll. Houhun Li (NKUM); 20̂, Maoba, Lichuan,

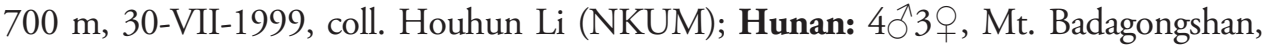
Sangzhi, 1250 m, 12-VIII-2001, coll. Houhun Li, Xinpu Wang (NKUM); $3{ }^{\lambda}$, Zhangjiajie, 650 m, 7-11-VIII-2001, coll. Houhun Li, Xinpu Wang (NKUM); Sichuan: 10ิ, Labahe, Tianquan, $30^{\circ} 09^{\prime} \mathrm{N}, 102^{\circ} 26^{\prime} \mathrm{E}, 1860 \mathrm{~m}$, 8-VII-2012, coll. Jinwei Li, genitalia slide no. LJW12250; Tibet: $1 \delta^{\lambda}$, Dexing, Motuo, $29^{\circ} 20^{\prime} \mathrm{N}, 95^{\circ} 18^{\prime} \mathrm{E}$, $835 \mathrm{~m}$, 9-VII-2013, coll. Jinwei Li, genitalia slide no. LJW12209; 10, Pailong, Linzhi, 3001'N, 9500'E, $2010 \mathrm{~m}$,

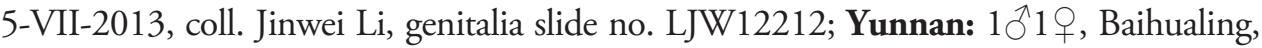
Baoshan, 1520 m, 11-13-VIII-2007, coll. Dandan Zhang, genitalia slide no. LJW12160 (ठ̊); 1ठ, Haba, Diqing, 15-VII-2011, coll. Jinwei Li, genitalia slide no. LJW12153.

Distribution. China (Fujian, Guangxi, Guizhou, Hubei, Hunan, Sichuan, Tibet, Yunnan), Japan.

\section{Udea stationalis Yamanaka, 1988, new record to China}

Udea stationalis Yamanaka, 1988: 111. Type locality: Japan, Honshu.

Diagnosis. This species is similar to other species of $U$. lugubralis-complex. It can be distinguished from $U$. lugubralis by smaller size (wingspan 15-20 mm). Differs from 
both $U$. lugubralis and $U$. exigualis by somewhat straight harpe, by lacking granularly membranous interval zone between antrum and colliculum. Differs from U. montensis by the phallus apodeme lacking the small lateral tooth-like process, and by lacking granularly membranous interval zone between antrum and colliculum.

Material examined. China: Fujian: 19 , Guadun, Mt. Wuyishan, $27^{\circ} 74^{\prime} \mathrm{N}$, $117^{\circ} 64^{\prime} \mathrm{E}, 1220 \mathrm{~m}, 18-\mathrm{V}-2012$, coll. Jinwei Li, genitalia slide no. LJW12154.

Distribution. China (Fujian), Japan.

\section{Udea curvata sp. $\mathrm{n}$.}

http://zoobank.org/0E665363-306D-4736-AB9B-47CF4B8E5869

Figs 1,4

Type-locality. China, Tibet, Milin, Paizhen, 29³0'N, 94 51'E, 2961 m, 2-VII-2013, coll. Jinwei Li.

Type material. Male holotype, China: Tibet: Paizhen, Milin, $29^{\circ} 30^{\prime} \mathrm{N}, 94^{\circ} 51^{\prime} \mathrm{E}$, 2961 m, 2-VII-2013, coll. Jinwei Li, genitalia slide no. LJW12172 (SYSBM); Paratypes. $3{ }^{\prime}$, China: Tibet: Paizhen, Milin, 29³0'N, 9451'E, 2961 m, 2-3-VII-2013, coll. Jinwei Li, genitalia slides no. LJW12248, LJW12267 (SYSBM). Additional material. 1 abdomen missing, China: Tibet: Paizhen, Milin, 29³0'N, 94 $51^{\prime} \mathrm{E}, 2961 \mathrm{~m}$, 2-VII-2013, coll. Jinwei Li.

Diagnosis. This species is similar to $U$. decrepitalis and $U$. elutalis with zigzaggy serrated postmedian line and darker postmedian area of forewing, but can be distinguished in: fibula claw-shaped, bent, with point apex; phallus with a thumb-shaped cornutus. Differs from $U$. decrepitalis also by colouration of forewing stigmata identical with ground colour. $U$. curvata is similar to $U$. conubialis in male genitalia, but can be distinguished in: wingspan $25.5-28.5 \mathrm{~mm}$, ground colour yellow, postmedian line zigzaggy, proximal cellular stigma distinct, fibula strongly bent. $U$. curvata similar to $U$. lutealis with yellow ground colour and colouration of forewing stigmata identical with ground colour, but can be distinguished by bent fibula extending ventro-distally, juxta bifid ventrally, phallus with a thumb-shaped cornutus, posterior phallus with granulated area not sclerotised, and lacking projecting denticulate ridge most posteriorly.

Description. Male (Fig. 1). Wingspan 25.5-28.5 mm. Frons yellowish-brown, with white lateral band not extending to anterior end, and a faint, short middle band. Vertex pale yellowish-brown. Labial palpus slightly upturned obliquely, third segment porrect; length about 2.5 times diameter of eye; yellowish-brown, contrastingly white at base ventrally. Maxillary palpus yellowish-brown, with a brush of scales. Basal scaling of proboscis white. Antenna with yellowish-brown scales dorsally. Thorax and abdomen yellow dorsally, dirty white ventrally. Legs creamy white, foreleg inner side dark yellowish.

Forewing yellow, scattered with brown scales, markings grey-brown; antemedian line from costal $1 / 4$ sinuated to $1 / 3$ posterior margin; proximal cellular stigma circular; distal cellular stigma kidney-shaped; postmedian line zigzaggy serrate, from costal 3/4, 

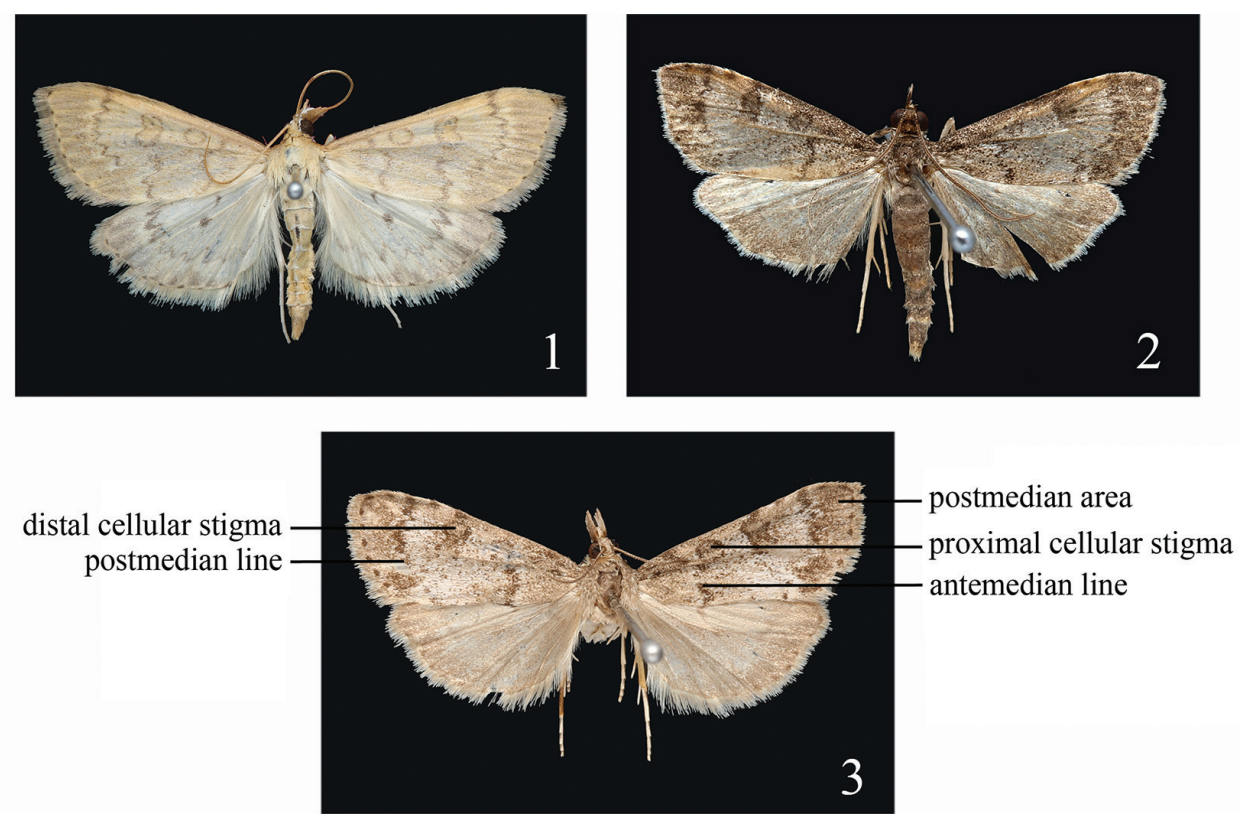

Figures I-3. Adults of Udea species. I U. curvata sp. n., male, paratype, Paizhen 2-3 U. albostriata sp. n. $\mathbf{2}$ paratype, male, Taomugeda $\mathbf{3}$ paratype, female, Taomugeda.

excurved around cell, and strongly inflexed below distal cellular stigma, then to $2 / 3$ on posterior margin; postmedian area strongly dusted with grey and alternately formed grey and yellow streaks; vein ends on wing margin each with a small brown dot; fringe yellow, basal 1/4 grey. Hindwing pale yellow, a darker steak at anterior angle and a blackish dot at posterior angle of cell; postmedial line grey-brown, zigzaggy serrate, with anterior 1/4 most distinct; postmedian area similar to forewing, marginal line and fringe as forewing, paler at tornus area.

Male genitalia (Fig. 4). Uncus inverted T-shaped, with base expanded, apex bulbous and setose dorso-laterally. Pseudognathos slender and ribbon-like, semicircular produced medially. Triangular transtilla connected. Valva narrow and long, costa nearly straight, proximal half of costa twice as broad as distal half, ventral margin broadly sinuate basally, with a stout tip protruding proximal of the distal end of sacculus, nearly parallel to costa from middle to end; fibula claw-shaped, bent ventro-distally, with point apex. Saccus inflated, ventrally keeled. Juxta nearly circular, somewhat bifid ventrally, dorsal edge serrated. Phallus cylindrical, with a short coecum, with a thumb-shaped cornutus, posterior phallus with granulated vesica.

Female unknown.

Distribution. China (Tibet).

Etymology. The specific name is derived from the Latin curvata = curved, referring to the curved fibula. 


\section{Udea prunalis (Denis \& Schiffermüller, 1775), new record to China}

Pyralis prunalis Denis \& Schiffermüller, 1775: 121. Type locality: Austria, Vienna environs. Phalaena nivealis Fabricius, 1781: 274.

Phalaena Pyralis ferruginalis Villers, 1789: 451.

Pyralis leucophaealis Hübner, 1796: 27.

Pyralis nebulalis Haworth, 1811: 386.

Pionea prunalis (Denis \& Schiffermüller): Hampson 1899: 243.

Udea prunalis (Denis \& Schiffermüller): Hasenfuss 1960: 182.

Diagnosis. $U$. prunalis is similar to $U$. cyanalis, U. inquinatalis (Lienig \& Zeller), $U$. orbicentralis-complex and $U$. albostriata sp. n. with greyish white ground colour of forewing variably dusted with dark brown, proximal cellular stigma, distal cellular stigma and postmedian area strongly and contrastingly dark browned, but can be distinguished from them in: cornuti composed of a row of linked short spines, a row of closely squeezed long spines and a single longer spine in male genitalia, the mid-folded ductus bursae with posterior half sclerotised and plate-shaped accessory signum in female genitalia.

Material examined. China: Gansu: $5 \delta^{\hat{}} 3$ 우, Mt. Xinglongshan, Yuzhong, 2120

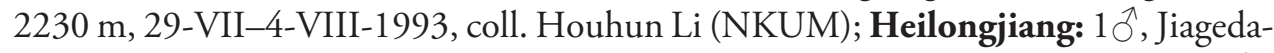
qi, 14-VII-2012, coll. Dandan Zhang, Lijun Yang, genitalia slide no. LJW12157 (ð゙); Ningxia: $1 \overbrace{}^{\lambda}$, Xinmin Forestry Station, Jingyuan, 2100 m, 7-VIII-2000, coll. Houhun Li, Shuxia Wang (NKUM); Shanxi: 1 \% , Xiachuan, Qinshui, $35^{\circ} 26^{\prime} \mathrm{N}, 112^{\circ} 00^{\prime} \mathrm{E}$, 1555 m, 24-VII-2013, coll. Weicai Xie; Sichuan: $10{ }^{\lambda} 6$ 으, Rize, Jiuzhaigou, 2700 m, 13-VIII-2002, coll. Shulian Hao (NKUM); 1ð, Shuzheng, Jiuzhaigou, 2300 m, 17-VIII-2002, coll. Shulian Hao (NKUM); 11 3우, Zhawa, Jiuzhaigou, $2400 \mathrm{~m}$, 15-VIII-2002, coll. Shulian Hao (NKUM); Xinjiang: 10, Kuerdening, Gongliu, 2230 m, 28-VII-1994, coll. Houhun Li, Hongyan Qin (NKUM); 19, Kuerdening, Gongliu, $43^{\circ} 10^{\prime} \mathrm{N}, 82^{\circ} 52^{\prime} \mathrm{E}, 1483 \mathrm{~m}, 22-\mathrm{VII}-2013$, coll. Jinwei Li, genitalia slide no. LJW12254.

Distribution. China (Gansu, Heilongjiang, Ningxia, Shanxi, Sichuan, Xinjiang), Europe (except some Mediterranean Islands).

\section{Udea elutalis (Denis \& Schiffermüller, 1775), new record to China}

Pyralis elutalis Denis \& Schiffermüller, 1775: 121. Type locality: Austria, Vienna environs. Pyralis albidalis Hübner, 1796: fig. 118.

Udea elutalis (Denis \& Schiffermüller): Hasenfuss 1960: 182.

Diagnosis. This species is similar to $U$. lutealis (Hübner), but can be distinguished by a wide, blade-shaped fibula with a minute, hook-like apex, by praephallus with cornuti a tight line of spines in male genitalia. U. elutalis with antrum narrower than colliculum in female genitalia but contrary in $U$. lutealis. 


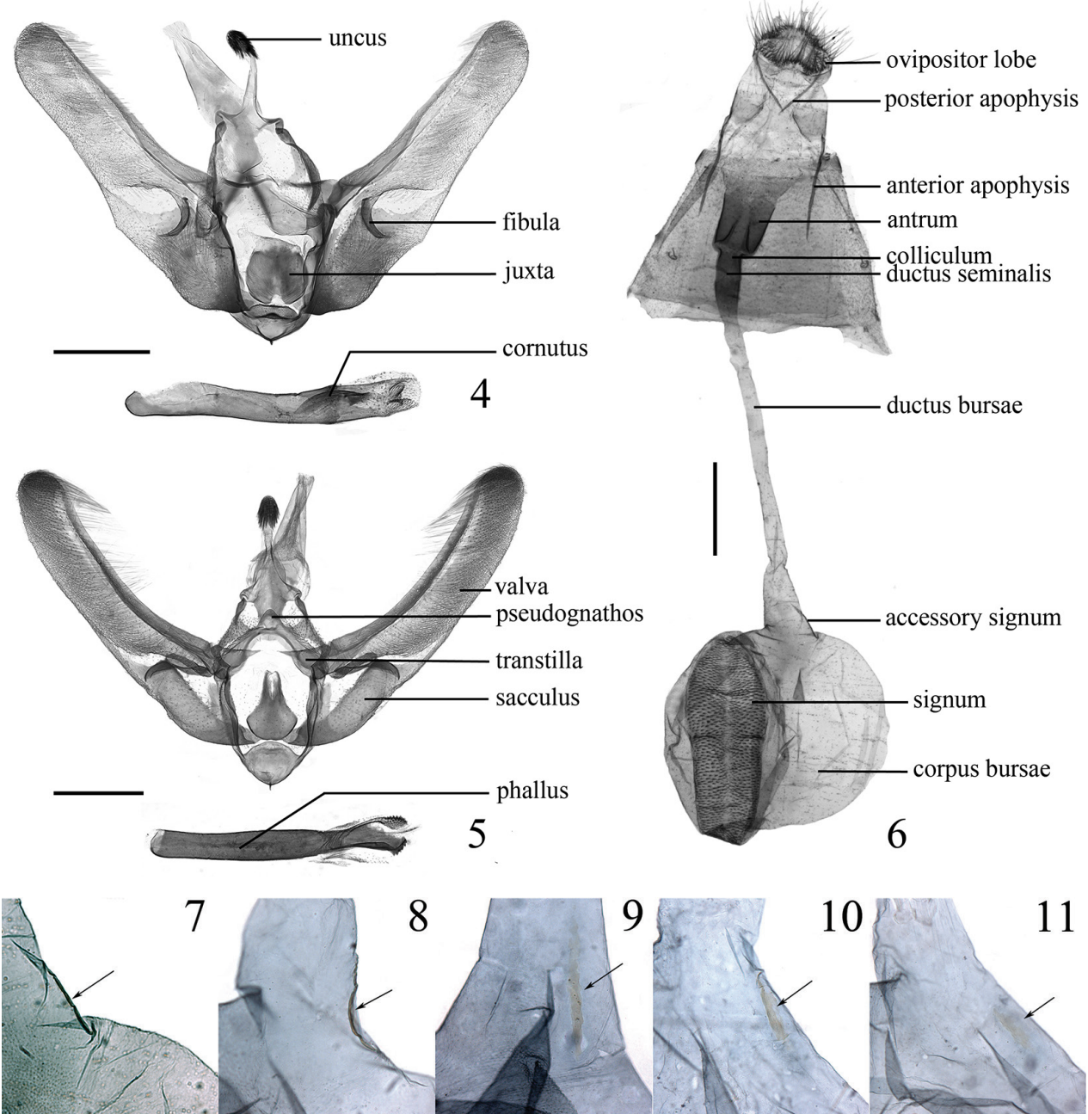

Figures 4-II. Genitalia of Udea species. 4 Male genitalia of $U$. curvata sp. n., genitalia slide no. LJW12267 5-II U. albostriata sp. n. 5 Male genitalia, genitalia slide no. LJW12288 6 Female genitalia, genitalia slide no. LJW12296 7-I I Variation of accessory signum, genitalia slides no. LJW12296, LJW12297, LJW12292, LJW12284, LJW12287. Scale bars: $0.5 \mathrm{~mm}$.

Material examined. China: Hebei: $32 \curvearrowright 13 q$, Taomugeda, Laiyuan County, $39^{\circ} 37^{\prime} \mathrm{N}, 114^{\circ} 59^{\prime} \mathrm{E}, 1420 \mathrm{~m}, 3-\mathrm{VIII}-2013$, coll. Weicai Xie, Xiaolin Liu, genitalia slides no. LJW12174 (ふ), LJW12203 (), LJW12243 (ふ), LJW12244 (), LJW12268

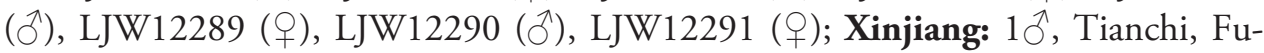

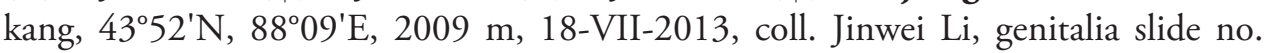

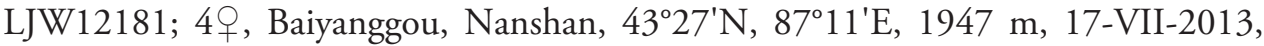
coll. Jinwei Li, genitalia slides no. LJW12202, LJW12294. 
Remarks. There is considerable variation in size of wingspan, ground colour and genitalia. The specimens from Hebei have whitish or whitish-grey forewing, with small wingspan size (18-22 $\mathrm{mm}$ ). The specimens from Hebei and Xinjiang exhibit a slightly curved and shorter row of spines in the posterior phallus compared to material from Europe and Russia (Bolshakov, 2002; Slamka, 2013). In the female genitalia, the accessory signum varies from crescent- or stick-shaped over gradual reduction to complete absence.

Distribution. China (Hebei, Xinjiang), Kazakhstan, West Europe, Central Europe, Romania, Balticstates, Finland, Russia (Siberia).

\section{Udea cyanalis (La Harpe, 1855), new record to China}

Botys cyanalis La Harpe, 1855: 30. Type locality: Europe. Udea cyanalis (La Harpe): Hannemann 1964: 322.

Diagnosis. $U$. cyanalis is similar to $U$. prunalis, $U$. inquinatalis, $U$. orbicentralis-complex and $U$. albostriata sp. $n$. with similar ground colour and maculation as mentioned in diagnosis of $U$. prunalis, but can be distinguished from them by the semicircular produced process of pseudognathos with nipple-shaped end in male genitalia. In female genitalia, this species differs from $U$. prunalis, $U$. inquinatalis and $U$. grisealis Inoue, Yamanaka \& Sasaki by ductus bursae approximately 1.8 times the length of the corpus bursae, the corpus bursae with narrowly crescent-shaped accessory signum, but lacking the lanceolate signum; differs from $U$. nebulatalis Inoue, Yamanaka \& Sasaki by ductus bursae approximately 1.8 times the length of the corpus bursae and nearly round corpus bursae; differs from $U$. proximalis Inoue, Yamanaka \& Sasaki and $U$. intermedia Inoue, Yamanaka \& Sasaki by crescent-shaped accessory signum but lacking the lanceolate or pyriform signum; differs from $U$. orbicentralis and $U$. albostriata sp. n. by lacking the lanceolate signum.

Material examined. China: Hebei: $2{ }^{\lambda}$, Taomugeda, Laiyuan County, $39^{\circ} 37^{\prime} \mathrm{N}$, 11459'E, 1420 m, 3-VIII-2013, coll. Xiaolin Liu, genitalia slides no. LJW12282, LJW12293.

Distribution. China (Hebei), Spain, France, Herzegovina, Romania, Germany, Central Urals, Russia (Caucasus).

\section{Udea albostriata sp. $\mathbf{n}$.}

http://zoobank.org/B4A2764A-7681-411A-AEFA-BFD4686B8BBE

Figs 2, 3, 5-11

Type-locality. China, Hebei, Laiyuan County, Taomugeda, $39^{\circ} 37^{\prime} \mathrm{N}, 114^{\circ} 59^{\prime} \mathrm{E}$, 1420 m, 3-VIII-2013, coll. Xiaolin Liu. 
Type material. Male holotype, China: Hebei: Taomugeda, Laiyuan County, $39^{\circ} 37^{\prime} \mathrm{N}, 114^{\circ} 59^{\prime} \mathrm{E}, 1420 \mathrm{~m}$, 3-VIII-2013, coll.Xiaolin Liu, genitalia slide no. LJW12204 (SYSBM); Paratypes. $14{ }^{\wedge} 8$, same data as holotype, genitalia slides no. LJW12173

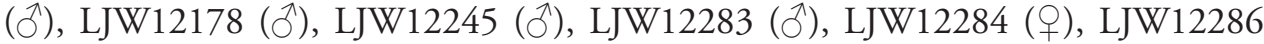
(), LJW12287 (), LJW12288 (ð), LJW12292 (ㅇ), LJW12296 () (SYSBM); 2q, Hebei: Jinhekou, Wei County, 3957'N, 11456'E, 1112 m, 5-VIII-2013, coll. Weicai Xie, Xiaolin Liu, genitalia slide no. LJW12297 (†) (SYSBM). Additional material. China: Hebei: 1 abdomen missing, Taomugeda, Laiyuan County, 39 $37^{\prime} \mathrm{N}, 114^{\circ} 59^{\prime} \mathrm{E}$, 1420 m, 3-VIII-2013, coll. Xiaolin Liu; 1 abdomen missing, Jinhekou, Wei County, $39^{\circ} 57^{\prime} \mathrm{N}, 114^{\circ} 56^{\prime} \mathrm{E}, 1112 \mathrm{~m}$, 5-VIII-2013, coll. Weicai Xie, Xiaolin Liu.

Diagnosis. $U$. albostriata is closely related to $U$. cyanalis, $U$. prunalis, $U$. inquinatalis, U. orbicentralis-complex with similar ground colour and maculation as mentioned in diagnosis of $U$. prunalis, but can be distinguished from $U$. cyanalis, $U$. nebulatalis, $U$. proximalis by corpus bursae with a lanceolate signum in female genitalia; differs from $U$. prunalis, $U$. inquinatalis, $U$. grisealis and $U$. intermedia by long ductus bursae about twice the length of the corpus bursae; differs from U. orbicentralis in: praephallus with a sclerotized, granulated area and a projecting ridge strongly denticulate, antrum much broader and shorter than in U. orbicentralis, and not bulged laterally.

Description. Wingspan 17-23 mm. Frons and vertex dark brown, dusted with light grey. Labial palpus slightly upturned obliquely, third segment porrect, dark brown, dusted with light grey, contrastingly white at base ventrally, length approximate three times the diameter of the eye. Maxillary palpus dark brown, dusted with light grey, with tip a brush of scales. Basal scaling of proboscis creamy white. Antenna with dark scales dorsally. Thorax dark greyish, dusted with light grey dorsally, greyishwhite ventrally. Abdomen grey to dark greyish dorsally, greyish-white ventrally. Legs greyish-white, with scattered few dark scales, sometimes mid- and hind-tibiae, tarsus dark brown, dusted with white outwardly.

Forewing ground colour greyish white, dusted with dark brown, proximal and distal cellular stigmata and postmedian area strongly and contrastingly dark browned; antemedian line from $1 / 5$ of costa oblique outwards to posterior margin of cell, then sinuating to $1 / 3$ of posterior margin; proximal cellular stigma transversely oval, dark brown, rimmed with blackish; distal cellular stigma nearly 8-shaped, coloured like proximal cellular stigma; postmedian line sinuate, from costal $4 / 5$ slightly arched to $3 / 5$ of $\mathrm{CuA}_{2}$, followed by a $\mathrm{V}$-shaped curve, then to $2 / 3$ of posterior margin, traced by a greyish-white line in postmedian area; marginal brown dots at vein ends on costa and termen; basal half of fringe pale grey, distal half dirty white. Hindwing grey, markings indistinct; a dark steak at anterior angle and a blackish dot at posterior angle of cell; postmedian line very indistinct, parallel with termen; fringe paler than in forewing.

Male genitalia (Fig. 5). Uncus with basal half nearly triangular, apex bulbous and setose dorso-laterally. Pseudognathos slender and ribbon-like, roundly triangular medially. Transtilla triangular. Valva narrow and elongate, costa slightly concave, slightly tapering in thickness towards apex, nearly parallel-sided with ventral valva edge; fibula extending ventrad, weakly sclerotised, blade-shaped, curved, with tip pointed; sacculus slightly 
inflated. Saccus ventrally keeled. Juxta broad ventrally, tapered dorsally, with dorsal $1 / 3$ bifid. Phallus cylindrical, slightly curved, with posterior phallus apodeme divided into a sclerotised, granulated area and a projecting denticulate ridge most posteriorly.

Female genitalia (Figs 6-11). Ovipositor lobes flat, crescent-shaped, densely setose. Anterior apophyses a little longer than posterior apophyses. Antrum sclerotised, nearly cylindrical, slightly tapering anteriorly, mesoventrally with two longitudinal ridges. Ductus bursae slender, about twice the length of the corpus bursae, slightly sclerotised posteriorly, colliculum short, ductus seminalis from ductus bursae close to colliculum. Corpus bursae nearly round, accessory signum (Figs 7-11) narrowly crescent-shaped, or weakly rod-shaped; signum lanceolate, ends rounded, with a mesally interrupted transverse ridge in the middle.

Distribution. China (Hebei).

Etymology. The specific name is derived from the Latin albus = white, striatus = striate, referring to forewing postmedian line traced by a greyish-white line in the postmedian area.

\section{Discussion}

Udea is one of the most species-rich genera of Spilomelinae. Until now, 31 Udeaspecies are recorded from China, but our knowledge about this fauna is still poor. For example, some of the species are only known by their original descriptions, based on type-localities in China.

Biogeographically, the northern part of China belongs to the Palaearctic region and the southern part to the Oriental region. The border is given by the Qinling Mountains and Huaihe River (Zheng and Zhang 1956). Accordingly, 15 of the Chinese $U d e a$-species belong to the Palaearctic fauna, nine to the Oriental fauna and seven occur in both of these or even more regions. Most of the Oriental species occur in the mountains. Therefore, Udea could be called a group of temperate regions as well as of mountain regions at more southerly latitudes.

Remarkably, 15 of the Udea species recorded from China are so far only known from China. They are distributed in southwestern Yunnan and Sichuan, northwestern Qinghai, Tibet and Xinjiang as well as on Taiwan. Understanding this pattern will require further faunistic investigations throughout China, and a phylogeographic analysis including areas outside China.

\section{Acknowledgements}

The first author wishes to express her thanks to Prof. Houhun Li (Nankai University, China) for the guidance of her doctoral thesis (some material listed in this paper). Two reviewers and Dr Matthias Nuss (Senckenberg Natural History Collections Dresden, Germany) provided valuable comments on the manuscript. We appreciate the assistance 
of Mr Hiroshi Yamanaka (4-18 Eiraku-cho, Toyama, Japan) for literatures and helpful comments. This project was supported by a Program of the Ministry of Science and Technology of the People's Republic of China (2015FY210300).

\section{References}

Bolshakov LV (2002) New species of pyraloid moths from the Centre of European Russia (Lepidoptera: Pyraustidae). Russian Entomological Journal 11(2): 225-228.

Butler AG (1879) Illustrations of typical specimens of Lepidoptera Heterocera in the collection of the British Museum. Printed by the order of the trustees, xviii +82 pp., 20 pls.

Butler AG (1882) On a small collection of Lepidoptera from the Hawaiian Islands. Transactions of the Entomological Society of London, 31-45.

Butler AG (1883) On a small series of Lepidoptera from the Hawaiian Islands. The Entomologist's Monthly Magazine 19: 176-180.

Caradja A (1916) Beitrag zur Kenntnis der geographischen Verbreitung der Pyraliden und Tortriciden des europäischen Faunengebietes, nebst Beschreibung neuer Formen. Deutsche entomologische Zeitschrift Iris 30(1): 1-88, errata 151-152.

Caradja A (1925) Ueber Chinas Pyraliden, Tortriciden, Tineiden nebst kurze Betrachtungen, zu denen das Studium dieser Fauna Veranlassung gibt (Eine biogeographische Skizze). Academia Romana Memoriile Sectiunii Stiintifice (seria 3) 3(7): 257-383, pls. 1-2.

Caradja A (1927) Die Kleinfalter der Stötzner'schen Ausbeute nebst Zuträge aus meiner Sammlung (Zweite biogeographische Skizze: "Zentralasien"). Memoriile Sectiunii Stiintifice. Academia Romana (ser. 3) 4(8): 361-428.

Caradja A (1928) Ueber einige neue und schon bekannte Pyraliden und Tortriciden aus dem palaearktischen Faunengebiete. Deutsche entomologische Zeitschrift Iris 42(3): 287-294.

Caradja A, Meyrick E (1937) Materialien zu einer Mikrolepidopterenfauna des Yülingshanmassivs (Provinz Yünnan). Deutsche entomologische Zeitschrift Iris 51(4): 137-182.

Chrétien P (1925) La Legende de Graellsia isabellae. Appendice. L'Amateur de Papillons 2(16): 241-247.

Christoph HT (1881) Neue Lepidopteren des Amurgebietes. Bulletin de la Société Impériale des Naturalistes de Moscou 56: 1-80.

Costantini A (1923) Lepidoptera pro fauna italica nova, additis specierum formarumque novarum descriptionibus. II. Neue Beiträge zur systematischen Insektenkunde 2(12): 105-107, pl. 7.

Curtis WP (1934) Lepidoptera at Maurin, Basses-Alpes, France (Addenda). The Entomologist's Record and Journal of Variation 46: 37-43.

Denis JNCM, Schiffermüller I (1775) Ankündung eines systematischen Werkes von den Schmetterlingen der Wienergegend herausgegeben von einigen Lehrern am k.k. Theresianum. Augustin Bernardi, Wien, 323 pp., pls. 1-3.

Dufrane A (1960) Microlépidoptères de la faune Belge (neuvième note). Bulletin de l'Institut Royal des Sciences Naturelles de Belgique 36(29): 1-16. 
Duponchel PAJ (1844-1846) [imprint 1844] Catalogue méthodique des Lépidoptères d'Europe distribués en familles, tribus et genres avec l'exposé des caractères sur lesquels ces décisions sont fondées, et l'indication des lieux et des époques où l'on trouve chaque espèce, pour servir de complément et de rectification à l'Histoire naturelle des Lépidoptères de France. Méquignon-Marvis Fils, Paris, xxx + [1] + 523 pp., pls. 75-90.

Eversmann EF (1852) Mittheilung über einige neue Falter Russlands. Bulletin de la Société Impériale des Naturalistes de Moscou 25(1): 148-169.

Fabricius JC (1781) Species insectorum exhibentes eorum differentias specificas, synonyma auctorum, loca natalia, metamorphosin adiectis observationibus, descriptionibus. Carol. Ernest. Bohnii, Hamburgi et Kilonii, 1-494, 495-514 (appendix), 515-517 (index).

Guenée MA (1854) Deltoides et Pyralites. In: Boisduval JBAD de, Guenée MA. Histoire Naturelle des Insectes. Species Général des Lépidoptères 8 8. Roret, Paris, 448 pp.

Hampson GF (1899) A revision of the moths of the subfamily Pyraustinae and family Pyralidae. Part II. Proceedings of the General Meetings for Scientific Business of the Zoological Society of London 1899(1): 172-291.

Hampson GF (1918) Descriptions of new Pyralidae of the subfamily Pyraustinae. Annals and Magazine of Natural History, including Zoology, Botany and Geology (ser. 9) 2: 181-196, 393-407.

Hannemann HJ (1964) Kleinschmetterlinge oder Microlepidoptera II. Die Wickler (s. 1.) (Cochylidae und Carposinidae). Die Zünslerartigen (Pyraloidea). In: Dahl F (1964) Die Tierwelt Deutschlands, 50. Teil 50. Gustav Fischer, Jena, i-viii, 401 pp., pls. 1-22.

Hasenfuss I (1960) Die Larvalsystematik der Zünsler (Pyralidae). Abhandlungen zur Larvalsystematik der Insekten 5: 1-263.

Haworth AH (1803-1828) Lepidoptera Britannica, sistens digestimen novam lepidopterorum quae in Magna Britannica reperiunter... adjuguntur dissertationes variae ad historiam naturalam spectantes. London, 609 pp.

Heinemann H (1865) Die Schmetterlinge Deutschlands und der Schweiz. Zweite Abtheilung. Kleinschmetterlinge. Band 1. Heft II. Die Zünsler. C. A. Schwetschke und Sohn, Braunschweig, i-vi, 1-214, 1-27.

Herrich-Schäffer GAW (1847-1855) [imprint “1849”] Systematische Bearbeitung der Schmetterlinge von Europa, zugleich als Text, Revision und Supplement zu Jakob Hübner's Sammlung europäischer Schmetterlinge. 4: Die Zünsler und Wickler. G. J. Manz, Regensburg, [1]-2-288, (Index) [1]-2-48, pls. 1-23 (Pyralidides) + 1-59 (Tortricides).

Heyden C (1860) Zwei neue Schmetterlinge aus dem Ober-Engadin. [Herminia modestalis, Botys sororialis]. Jahresbericht der Naturforschenden Gesellschaft Graubündens 5: 93-95.

Hübner J (1796-1833) Sammlung europäischer Schmetterlinge. 6. Horde. Die Zünsler; nach der Natur geordnet, beschrieben und vorgestellt (continued by C. Geyer). Augsburg, [i]-[iv], [i-ii], [i-ii], 1-30, [i-ii], [i-ii], pls. 1-32.

Inoue H (1982) Pyralidae. In: Inoue H, Sugi S, Kuroko H, Moriuti S, Kawabe A (Eds) Moths of Japan 1+2. Kodansha, Tokyo, 1: 307-404; 2: 223-254; pls. 36-48, 228, 296-314.

Inoue H (1993) On Udea tritalis (Christoph) (Pyralidae, Pyraustinae) from Japan. Japan Heterocerists' Journal 174: 420-421. 
Inoue H, Yamanaka H, Sasaki A (2008) Revision of Udea orbicentralis-complex from Japan, with descriptions of four new species (Pyralidae, Pyraustinae). Tinea 20(2): 85-94.

Krulikovsky L (1898) Opyt kataloga tscheschujekrylych Kasanskoi gubernii. Bulletin de la Société Impériale des Naturalistes de Moscou new series 12(1): 42-67.

La Harpe JJC (1855) Faune Suisse. Lépidoptères. V. Partie. Pyrales. Neue Denkschriften der Schweizerischen Naturforschenden Gesellschaft 14: [1]-[2], 3-75, 1 pl.

Leech JH (1889) New species of Deltoids and Pyrales from Corea, North China, and Japan. The Entomologist 22(310): 62-71, pls. 2-4.

Leech JH, South R (1901) Lepidoptera Heterocera from China, Japan, and Corea. Part V. Transactions of the Entomological Society of London, 385-514, pls. 14-15.

Li HH, Zheng ZM (1996) Methods and techniques of specimens of Microlepidopera. Journal of Shaanxi Normal University (Natural Science Edition) 24(3): 63-70.

Maes KVN (1995) A comparative morphological study of the adult Crambidae (Lepidoptera, Pyraloidea). Bulletin et Annales de la Société Royale Belge d'Entomologie 131: 383-434.

Mally R, Nuss M (2011) Molecular and morphological phylogeny of European Udea moths (Insecta: Lepidoptera: Pyraloidea). Arthropod Systematics \& Phylogeny 69(1): 55-71.

Meyrick E (1884) On the classification of the Australian Pyralidina. Transactions of the Entomological Society of London, 61-80, 277-350.

Meyrick E (1888) On the Pyralidina of the Hawaiian Islands. Transactions of the Entomological Society of London, 209-246.

Meyrick E (1899) Macrolepidoptera. In: Sharp D (Ed.) Fauna Hawaiiensis, vol. 1 part 21. University Press, Cambridge, 123-275, pls. 3-7.

Meyrick E (1930-1936) Exotic Microlepidoptera. Taylor and Francis, London, 642 pp.

Moore F (1888) Descriptions of new Indian lepidopterous insects from the collection of the late Mr. W.S. Atkinson. Heterocera (continued) (Pyralidae, Crambidae, Geometridae, Tortricidae, Tineidae). In: Hewitson WC, Moore F (Eds) Descriptions of new Indian lepidopterous Insects from the collection of the late Mr. W.S. Atkinson 3. Asiatic Society of Bengal / Taylor \& Francis, Calcutta / London, 199-299, pls. 6-8.

Munroe EG (1950) The generic positions of some North American Lepidoptera commonly referred to Pyrausta Schrank (Lepidoptera: Pyralidae). The Canadian Entomologist 82(11): 217-231. doi: 10.4039/Ent82217-11

Munroe EG (1966) Revision of the North American species of Udea Guenée (Lepidoptera: Pyralidae). Memoirs of the Entomological Society of Canada 49: 1-57. doi: 10.4039/ entm9849fv

Munroe EG (1989) Changes in classification and names of Hawaiian Pyraloidea since the publication of Insects of Hawaii, Volume 8, by E. C. Zimmerman (1958) (Lepidoptera). Bishop Museum Occasional Papers 29: 199-212.

Munroe EG (1995) Crambidae (Crambinae, Schoenobiinae, Cybalomiinae, Linostinae, Glaphyriinae, Dichogaminae, Scopariinae, Musotiminae, Midilinae, Nymphulinae, Odontiinae, Evergestinae, Pyraustinae). In: Heppner JB (Ed.) Atlas of Neotropical Lepidoptera, Checklist: Part 2. Hyblaeoidea-Pyraloidea-Tortricoidea 3. Association for Tropical Lepidoptera \& Scientific Publishers, Gainesville, 34-79. 
Mutuura A (1954) Classification of the Japanese Pyrausta group based on the structure of the male and female genitalia (Pyr.: Lep.). Bulletin of the Naniwa University (ser. B) 4: 7-33.

Nuss M, Landry B, Vegliante F, Tränkner A, Mally R, Hayden J, Segerer A, Li H, Schouten R, Solis MA, Trofimova T, De Prins J, Speidel W (2003-2014) Global Information System on Pyraloidea. www.pyraloidea.org

Robinson GS (1976) The preparation of slides of Lepidoptera genitalia with special reference to the Microlepidoptera. Entomologist's Gazette 27: 127-132.

Sauber CJA (1899) Neue paläarktische Mikrolepidopteren aus Centralasien. Verhandlungen des Vereins für Naturwissenschaftliche Unterhaltung zu Hamburg 10(1896-1898): 47-68.

Slamka F (2013) Pyraloidea of Europe, Volume 3 Pyraustinae and Spilomelinae. Bratislava, 357 pp.

Snellen PCT (1899) Eenige aanteekeningen over Pyraliden. Tijdschrift voor Entomologie 41(1898): 173-193, pls. 8-9.

Song SM (2001) Pyralidae. In: Huang BK (Ed.) Fauna of Insect in Fujian Province of China, Vol. 5. Lepidoptera, Moths. Fujian Science and Technology Press, Fuzhou, 101-226.

Strand EH (1918) Sauter's Formosa-Ausbeute: Pyralididae, Subfam. Pyraustinae. Deutsche entomologische Zeitschrift Iris 32(1-2): 33-91.

Strand E (1920) Beiträge zur Lepidopterenfauna Norwegens und Deutschlands. Archiv für Naturgeschichte 85(1919) Abt. A (4): 1-82.

Villers C (1789) Caroli Linnaei entomologia, faunæ Suecicæ descriptionibus aucta. Piestre \& Delamollière, Lyon [Lugduni], i-xvi, 656 pp.

Walker F (1859) Pyralides. List of the Specimens of Lepidopterous Insects in the Collection of the British Museum, London 18: 509-798, 19: 799-1036.

Walker F (1863) Crambites \& Tortricites. List of the Specimens of Lepidopterous Insects in the Collection of the British Museum 27: 1-286.

Warren W (1896) New genera and species of Pyralidae, Thyrididae, and Epiplemidae. Annals and Magazine of Natural History, including Zoology, Botany and Geology (ser. 6) 17: 94-106.

Wileman AE (1911) New and unrecorded species of Lepidoptera Heterocera from Japan. Transactions of the Entomological Society of London (2): 189-407, pls. 30-31. doi: 10.1111/j.1365-2311.1911.tb03088.x

Xu ZG (1997) Atlas of Small Moths in Qinghai. China Agricultural Science and Technology Press, Beijing, 186 pp.

Yamanaka H (1972) Notes on the Pyralidae from Formosa I. Tinea 9(1): 261-275, pls. 87-89. Yamanaka H (1988) Revision of the Udea lugubralis-complex (Lepidoptera: Pyralidae) from Japan, with description of a new species. Tinea 12(12): 105-112.

Zerny H (1914) Über paläarktische Pyraliden des k. k. naturhistorischen Hofmuseums in Wien. Annalen des naturhistorischen Hofmuseums 28(3-4): 295-348, pls. 25-26.

Zheng ZX, Zhang RZ (1956) On tentative scheme for dividing zoogeographical regions of China. Acta Geographica Sinica 22(1): 93-109.

Zimmerman EC (1958) Insects of Hawaii, Lepidoptera: Pyraloidea. University of Hawaii Press, Honolulu, 8: i-xii, 456 pp. 